\title{
MODIFICATION OF THE RHEOLOGICAL PROPERTIES OF SUBSTANDARD QUALITY WHEAT DOUGH WITH DIFFERENT DOSES OF SELECTED ENZYMES
}

\author{
Olivera D. Šimurina* ${ }^{* 1}$, Bojana V. Filipčev ${ }^{1}$, Tamara R. Dapčević Hadnađev ${ }^{1}$, Bojana B. Ikonić ${ }^{2}$ \\ Marija I. Bodroža Solarov ${ }^{1}$ \\ ${ }^{1}$ University of Novi Sad, Institute of Food Technology, Bulevar cara Lazara 1, 21000 Novi Sad, Serbia \\ ${ }^{2}$ University of Novi Sad, Faculty of Technology, Bulevar cara Lazara 1, 21000 Novi Sad, Serbia
}

\author{
${ }^{*}$ Corresponding author: \\ Phone: +381214853778 \\ E-mail address: olivera.simurina@fins.uns.ac.rs
}

\begin{abstract}
The objective of this study was to analyze the individual and synergistic effects of three enzyme preparations (transglutaminase, lipase and xylanase) on the viscoelastic properties of wheat dough made from flour of substandard quality. A response surface methodology using Box-Behnken experimental design was used to evaluate the effects on the dynamic and creep-recovery parameters of dough. The results confirmed that the strengthening effect were observed by transglutaminase and lipase addition. The storage modulus increased with transglutaminase and lipase addition applied in doses of $15 \mathrm{mg} / \mathrm{kg}$ to $30 \mathrm{mg} / \mathrm{kg}$, whilst xylanase (applied in doses of $25-50 \mathrm{mg} / \mathrm{kg}$ ) had no significant effect on dough storage modulus ( $\left.G^{\prime}\right)$. Significant interaction effects of transglutaminase and xylanase $(P \leq 0.1)$ increased the values of zero shear viscosity $\left(\eta_{0}\right)$. The optimal levels of the tested enzymes were determined by the desirability function approach. It was found that the combined effect of 30.0 $\mathrm{mg} / \mathrm{kg}$ of transglutaminase, $28.1 \mathrm{mg} / \mathrm{kg}$ of lipase and $38.6 \mathrm{mg} / \mathrm{kg}$ of xylanase achieved a positive synergistic effect on wheat dough viscoelasticity made from flour of substandard quality.
\end{abstract}

Key words: substandard quality flour, optimization, enzymes, creep-recovery test, response surface methodology

\section{INTRODUCTION}

In last decade, a variation of technological quality of mercantile wheat has been observed. This phenomenon is present not only in Serbia, but also in the neighbouring countries, across the whole Pannonian Plain. Wheat breeders are constantly creating new wheat varieties resistant to abiotic stress. However, the utilization of their potential is restricred due to inadequate application of agrotechniques. All the aforementioned facts affects the processing industry having to deal with great quantities of wheat flour of substandard quality.
The processing industry is assig-ned the task to elevate the quality of wheat flour to the level optimal for processing (Mikhaylenko et al., 2000; Malešević et al., 2011; Balla et al., 2011). In this context, the treatment of flours with functional additives must be considered. Nowadays, the baking industry is deeply involved in research for alternatives to chemical compounds because of their potential hazards (Fisher et al., 1979; Dupuis, 1997). The use of enzymes is the best alternative to chemical compounds because they are 
generally recognized as safe and do not remain active after baking. The enzymes act by different mechanisms and can induce changes in the forms of polymerized subunits of glutenin and become soluble proteins by improving their functional properties. One of the enzymes that can confer strength to dough is transglutaminase.

Transglutaminase (protein-glutamine $\gamma$-glutamyltransferase) (TG) catalyses the reaction of transfer of acyl group between $\gamma$ carboxamide group from protein bound glutamine residue (acyl donors) and different primary amines (acyl acceptors). As a result of this reaction, there occurs interor intra-molecular cross-linking in covalent bonds in a protein or peptide (Gerrard et al., 1998; Larré er al., 2000). In the case of gluten, this enzyme induced the formation of high molecular weight polymers and the formation of these polymers results in strengthening of gluten network (Larré et al., 2000). The investigations showed that TG can improve dough elasticity and it may also produce beneficial effects during breadmaking that are similar to oxidising improvers (Gerrard et al., 1998).

Lipase (1(3)-positional specificity) (LP) is an enzyme which hydrolyses ester bonds of fatty acids primarily in the 1- and 3-position in triglycerides. Products of hydrolysis are: diacylglycerol (DAG), monoacyIglycerols (MAG), glycerol and free fatty acids. The incurred hydrolysis products have properties of surfactants and encourage positive change in the interaction between the lipids and gluten (PrimoMartin et al., 2006). Lipases show good dough conditioning effects in terms of improved dough rheological properties, dough stability in case of over fermentation, increas oven spring and improve crumb structure in dough systems ( $\mathrm{Si}$, 1997).

Xylanase (endo- $\beta$-1.4-xylanases) (Xyl) is an enzyme which degrades linear polysaccharide beta-1.4-xylan into xylose. When xylanases are used at optimum levels, they play a significant role in improving dough and bread properties (Butt et al., 2008).
Small deformation of dynamic rheological tests and creep-recovery measurements are often applied for dough characterization and the derived rheological data are explored as predictors of breadmaking performance (Safari-Ardi and Phan-Thien, 1998; Edwards et al., 1999; 2001; Collar and Bollain, 2004). The usage of TG, LP and $\mathrm{Xyl}$ as dough improvers is well known and established (Joye et al., 2009; Valeri et al., 2011; Colakoglu and Özkaya, 2012). The innovative character of the paper lies in the fact that so far there has been no research of the combined effects of these enzymes in flour of substandard quality.

Response surface methodology (RSM) is a statistical technique that has been successfully applied in the development and optimization of cereal products (Ylimaki et al., 1988; Gallagher et al., 2003; Šimurina et al., 2012). The objective of the presented study was to evaluate the combined effects of transglutaminase, lipase and $x y$ lanase addition on the dough viscoelastic properties, using small deformation mechanical testing and explore the possibility of improving behavior during handling the dough of substandard flour.

\section{MATERIALS AND METHODS}

Commercial soft wheat flour was used in this study. This flour was obtained from local soft wheat and has the following characteristics: protein content of $10.7 \%$ of dry weight, dough energy determined Brabender by Extensograph of $32 \mathrm{~cm}^{2}$, resistance by Extensograph of $130 \mathrm{BU}$, extensibility by Extensograph of $157 \mathrm{~mm}$ and ratio number of the resistance to extensibility of $0.83 \mathrm{BU} / \mathrm{mm}$. Protein content of the tested wheat flour ( $\mathrm{N} \times 5.70)$ was analysed using a Kjeldahl procedure (ICC Standard No 105/2). Rheological properties were determined by the Brabender ${ }^{\circledR}$ Extensograph (ICC Standard No 114/1).

Three commercial enzymes were used: $\begin{array}{llll}\text { xylanase } & \left(V^{2} R O N^{\circledR}\right. & 191 & \text { S), lipase }\end{array}$ $\left(V E R O N^{\circledR}\right.$ Hyperbake-T) and transglutaminase $\left(V E R O N^{\circledR} T G\right)$, produced by company „AB Enzymes“ (Germany). The enzymes were applied to wheat dough in order to optimize its rheological parameters: storage modulus ( $\left.G^{\prime}\right)$, loss modulus (G"), zero shear viscosity $\left(\eta_{0}\right)$, maximum creep com- 
pliance $\left(\mathrm{J}_{\max }\right)$, and elastic part of the maximum creep compliance $\left(\mathrm{J}_{\mathrm{e}} / \mathrm{J}_{\max }\right)$. The combinations of enzymes were used following an experimental design for sampling and added at three addition levels coded as -1 (without enzyme), 0 (the minimal dose of the enzymes according to the manufacturer's specification) and 1 (the maximum dose of the enzymes according to the manufacturer's specification) (Table 1).

\section{Dough preparation for rheological tes- ting}

All the dough samples were mixed in a Farinograph bowl (Brabender, Germany) until the consistency of 500 BU was reached and continued for 8 minutes. Prepared doughs were placed in a plastic bag and immediately sealed and allowed to rest for $30 \mathrm{~min}$ at ambient temperature before rheological testing. Oscillatory and creep-recovery tests were performed using a HAAKE MARS rheometer (Thermo Scientific, Karlsruhe, Germany). The rheometer was equipped with a $35-\mathrm{mm}$ parallel plate measuring geometry. The plates were serrated in order to prevent the dough slippage. A dough sample was placed on the lower plate, and the upper plate was lowered until the gap of $1.0 \mathrm{~mm}$ was reached. The excess dough was trimmed and the edges were sealed with a paraffin oil to prevent the dough from drying during measurements. All the experiments were performed at $30^{\circ} \mathrm{C}$.

The experiment firstly involved frequency sweep test in the frequency range from 1 to $10 \mathrm{~Hz}$, since this measurement caused no changes in the dough structure when carried out at the chosen strain amplitude $(0.01 \%)$, and subsequently of a creep-recovery test. Preliminary strain sweep tests were used to determine the linear viscoelastic region of the doughs and from these measurements a strain level of $0.01 \%$, within the linear region, was adopted in all experiments. The storage modulus and loss modulus were continuously monitored during dynamic rheological testing in the frequency range from 1 to 10 $\mathrm{Hz}$ and their value at $1 \mathrm{~Hz}$ was used as the response variable in the model.

Creep and recovery were measured at a shear stress of $50 \mathrm{~Pa}$ for $300 \mathrm{~s}$, followed by a recovery phase of $900 \mathrm{~s}$ at a stress of $0 \mathrm{~Pa}$.

\section{Experimental design}

Three factorial Box-Behnken experimental design was used to examine the effects of enzymes (TG, LP, Xyl) on storage modulus ( $\left.G^{\prime}\right)$, loss modulus ( $G$ "), maximum creep compliance (Jmax), zero shear viscosity $\left(\eta_{0}\right)$ and elastic part of the maximum creep compliance (Je/Jmax). The factor levels were determined on the basis of minimal and maximal doses prescribed by enzymes manufacturer and coded as -1 (without enzyme), 0 (minimal dose) and 1 (maximal dose). The plan of experimental design is given in Table 1.

The relationships between the measured variables and the three independent factors (TG, LP and Xyl) were estimated by fitting the data to a second-order polynomial (Eq. (1)), where $\mathrm{Y}$ is the modeled response variable (e.g. storage modulus (G'), loss modulus (G"), maximum creep compliance $\left(J_{\max }\right)$, zero shear viscosity $\left(\eta_{0}\right)$, and elastic part of the maximum creep compliance $\left.\left(\mathrm{Je} / \mathrm{J}_{\max }\right)\right), \mathrm{b}_{0}$ is the intercept, $b_{1}$ and $b_{2}$ represent linear effects, $b_{11}$ and $b_{22}$ represent quadratic effects and $b_{12}$ represents interaction effects.

Coefficients of determination $\left(R^{2}\right)$ were computed, and the adequacy of models was tested by estimating the lack of fit. A stepwise deletion of non-significant terms was applied. The statistically non-significant linear terms were included in the model when their respective quadratic or interactive terms were statistically significant.

Calculation of optimal enzyme concentrations for increasing quality of wheat dough was performed using a multiple response method called desirability function.

The data were analysed using the Design Expert 8.0 software (Stat-Ease, Inc., Minneapolis, MN, USA).

$$
Y=b_{0}+b_{1} T G+b_{2} L P+b_{3} X y l+b_{12} T G \bullet L P+b_{13} T G \bullet X y l+b_{23} L P \bullet X y l+b_{11} T G^{2}+b_{22} L P^{2}+b_{33} X y l^{2}
$$




\section{RESULTS AND DISCUSSION}

The results of the experimental design, showing the effects of enzyme levels, are displayed in Table 1. The highest value of elastic part of the maximum creep complience $\left(\mathrm{J}_{\mathrm{e}} / \mathrm{J}_{\max }\right)$ was achieved in the experiment number 6 due to synergistic effects of the TG and LP. Synergistic action on cross-linking enzymes and hydrolytic enzymes achieved a positive effect on viscoelastic performance of wheat dough from substandard flour.

The consequence of synergistic effects of TG $(30 \mathrm{mg} / \mathrm{kg})$ and LP $(15 \mathrm{mg} / \mathrm{kg})$ was the decrease of the maximum creep compliance $\left(J_{\max }\right)$ to minimal value (Figure 1$)$. These results were probably due to the strengthening action exerted by TG due to its crosslinking effect on different flour protein fractions (Autio et al., 2005).

On the other hand, activity of lipase induced positive effect by hydrolyzing nonpola $r$ lipids (triacilglicerol) into more polar (monoacylglycerols and free fatty acids). According to Poulsen and Borch Søe (1997) the (ionic) salt form of the FFAs formed improves gluten complex formation and creates more lamellar gas cell interfaces and lipoprotein complexes. The enzymatic treatment probably caused a reinforcement of the gluten network which reduced the maximum compliance of the dough during the influence of stress. This increased dough formability by providing suitable elasticity and reduced stickiness.

The effects of individual and combined action of the investigated enzymes on viscoelastic characteristics are presented by the help of regression coefficient values on the basis of actual factors values given in Table 2. The mathematical models were evaluated statistically by the analysis of variance. Relatively high values of determination coefficient $\left(R^{2}\right)$ and insignificant lack of fit $(P \geq 0.05)$ point to an adequate fitting of the experimental results to the proposed method.

Table 1.

Experiment desing and results of the effect of enzymes on the rheological properties of wheat dough

\begin{tabular}{|c|c|c|c|c|c|c|c|c|}
\hline Runs & $\begin{array}{c}\mathrm{TG} \\
\mathrm{mg} / \mathrm{kg} \\
X_{1}\left(x_{1}\right)\end{array}$ & $\begin{array}{c}\begin{array}{c}\mathrm{LP} \\
\mathrm{mg} / \mathrm{kg}\end{array} \\
X_{2}\left(x_{2}\right)\end{array}$ & $\begin{array}{c}\begin{array}{c}X y l \\
\mathrm{mg} / \mathrm{kg}\end{array} \\
X_{3}\left(x_{3}\right)\end{array}$ & $\begin{array}{c}\mathrm{G}^{\prime}\left(\mathrm{x} 10^{3}\right) \\
\mathrm{Pa}\end{array}$ & $\begin{array}{c}\text { G" }\left(x 10^{3}\right) \\
\mathrm{Pa}\end{array}$ & $\underset{\mathrm{Pa}^{-1}}{\mathrm{~J}_{\max }\left(\mathrm{x} 10^{-3}\right)}$ & $\begin{array}{c}\mathrm{J}_{\mathrm{e}} / \mathbf{J}_{\max } \\
\%\end{array}$ & $\begin{array}{c}\eta_{0}\left(\times 10^{4}\right) \\
\text { Pa s }\end{array}$ \\
\hline Control & 0 & 0 & 0 & 11.2 & 4.9 & 0.94 & 56.1 & 63.5 \\
\hline 1 & $0(-1)$ & $0(-1)$ & $25(0)$ & 11.9 & 4.4 & 0.79 & 58.4 & 68.9 \\
\hline 2 & $30(1)$ & $0(-1)$ & $25(0)$ & 12.8 & 4.8 & 0.61 & 64.6 & 81.6 \\
\hline 3 & $0(-1)$ & $30(1)$ & $25(0)$ & 12.2 & 4.0 & 0.75 & 61.4 & 83.4 \\
\hline 4 & $30(1)$ & $30(1)$ & $25(0)$ & 14.0 & 4.5 & 0.60 & 63.1 & 86.9 \\
\hline 5 & $0(-1)$ & $15(0)$ & $0(-1)$ & 12.6 & 4.2 & 0.73 & 60.4 & 80.4 \\
\hline 6 & $30(1)$ & $15(0)$ & $0(-1)$ & 13.8 & 3.9 & 0.54 & 65.6 & 85.3 \\
\hline 7 & $0(-1)$ & $15(0)$ & $50(1)$ & 12.1 & 4.6 & 0.77 & 59.4 & 83.4 \\
\hline 8 & $30(1)$ & $15(0)$ & $50(1)$ & 12.7 & 4.3 & 0.63 & 62.5 & 86.9 \\
\hline 9 & $15(0)$ & $0(-1)$ & $0(-1)$ & 13.2 & 4.0 & 0.70 & 61.5 & 74.9 \\
\hline 10 & $15(0)$ & 30 (1) & $0(-1)$ & 12.5 & 4.5 & 0.73 & 63.8 & 85.1 \\
\hline 11 & $15(0)$ & $0(-1)$ & $50(1)$ & 12.8 & 4.8 & 0.77 & 62.8 & 76.8 \\
\hline 12 & $15(0)$ & $30(1)$ & $50(1)$ & 13.1 & 4.3 & 0.64 & 60.7 & 69.2 \\
\hline 13 & $15(0)$ & $15(0)$ & $25(0)$ & 12.7 & 4.3 & 0.74 & 61.3 & 77.5 \\
\hline 14 & $15(0)$ & $15(0)$ & $25(0)$ & 13.0 & 4.1 & 0.72 & 60.7 & 77.7 \\
\hline 15 & $15(0)$ & $15(0)$ & $25(0)$ & 12.5 & 4.2 & 0.70 & 60.3 & 77.2 \\
\hline
\end{tabular}




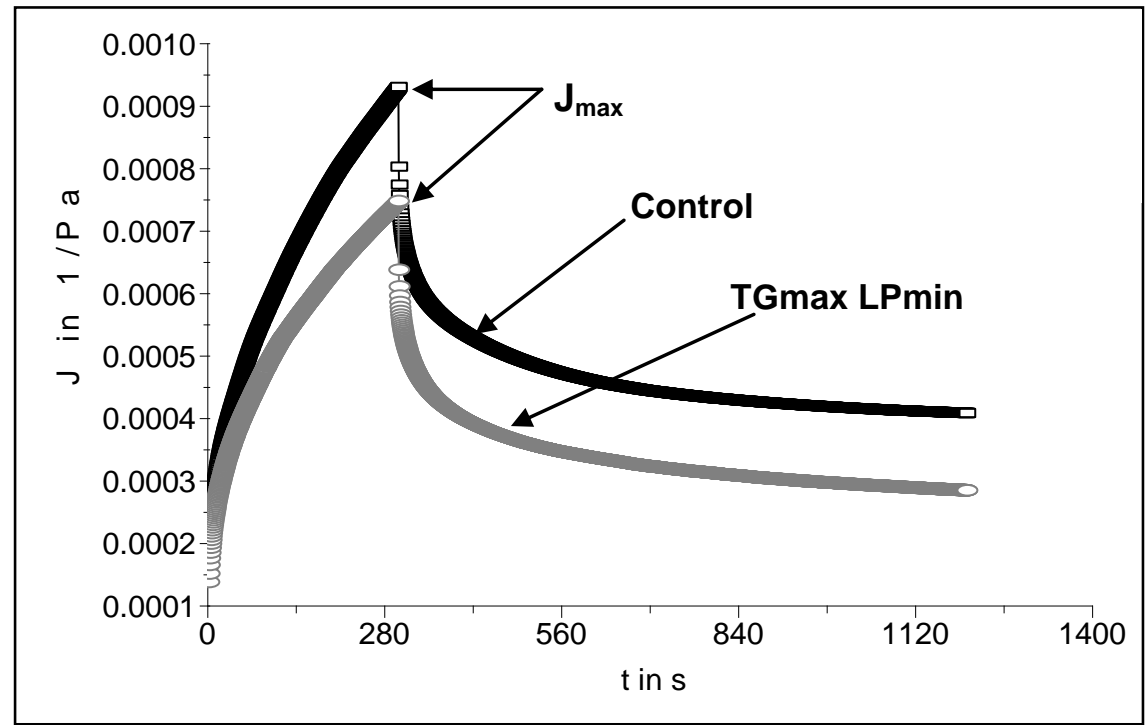

Figure 1. Creep-recovery curves showing the effect of transglutaminase $(30 \mathrm{mg} / \mathrm{kg})$ and lipase $(15$ $\mathrm{mg} / \mathrm{kg}$ ) on maximum creep compliance $\left(\mathrm{J}_{\max }\right)$

Table 2.

Significance coefficients and adequacy of regression models of dough made from substandard quality wheat flour

\begin{tabular}{|c|c|c|c|c|c|}
\hline $\begin{array}{l}\text { Regression } \\
\text { coefficients }\end{array}$ & $\mathbf{G}^{\prime}, \mathbf{P a}$ & G", Pa & $\mathrm{J}_{\max ,} \mathrm{Pa}^{-1}$ & $\mathbf{J}_{\mathrm{e}} / \mathbf{J}_{\max , \%}$ & $\eta_{0}, \mathrm{~Pa} s$ \\
\hline Intercept & 12573 & 4022,89 & 0,000702 & 62.467 & 777400 \\
\hline TG & $249.375^{*}$ & 107,42 & $-7,88 \mathrm{E}-02^{\star * *}$ & $328.625^{* * *}$ & 25706,3 \\
\hline LP & $259.375^{\star}$ & $-148.401^{* *}$ & $-4,08^{\star}$ & & $28100^{*}$ \\
\hline Xyl & & 104.397 & & & \\
\hline$T G * L P$ & $887,5^{\star *}$ & -187.969 & & & -22800 \\
\hline TG*Xyl & $-176,25$ & -150.848 & & & $6462,5^{*}$ \\
\hline LP*Xyl & 258,75 & -149.257 & & & -44600 \\
\hline$T^{2}{ }^{2}$ & & $104.188^{*}$ & & & $44631,2^{* *}$ \\
\hline $\mathrm{LP}^{2}$ & & $166.068^{*}$ & & & \\
\hline$\left.X y\right|^{2}$ & & $324,48^{*}$ & & & \\
\hline${ }^{\mathrm{a}} \mathrm{R}^{2}, \%$ & 61.2 & 75.6 & 60.6 & 72.3 & 78.8 \\
\hline$P$ value of ${ }^{b} L F$ & 0.68 & 0.80 & 0.59 & 0.70 & 0.7542 \\
\hline
\end{tabular}

${ }^{*} \mathrm{P} \leq 0.1 ;{ }^{* *} \mathrm{P} \leq 0.05 ;{ }^{* *} \mathrm{P} \leq 0.01 ; \mathrm{a}$-Coefficients of determination; $\mathrm{b}$-lack of fit

\section{Effect of enzymes on dynamic rheolo- gical properties of dough}

TG and LP have positive significant $(P \leq 0.1)$ linear effect on the storage modulus. Their interactive effect $\left(T G^{*} L P\right)$ is even higher and more significant $(P \leq 0.05)$, and influenced the increase of the storage modulus (G') which indicates dough elasticity. These results are achieved as a consequence of the effects of TG to networking of protein chains and strengthening of protein dough structure (Caballero et al., 2005; Buchert et al., 2007). The effect of lipases manifests as hydrolysis of wheat lipids, resulting in an in situ production of di- and monoglycerides, as well as saturated and polyunsaturated fatty acids, which have been shown to have a much stronger tendency to bind to gluten proteins and to cause gluten strengthening (Si and Drost-Lustenberg, 2002; Buchert et al., 2007). However, the square increase of the concentration of TG led to an insignificant effect on G', which imply that high TG doses would not expected to be efficient in dough elasticity improvement. These findings coincide with the research work of Rossel et al. (2003) who demonstrated that low levels of TG result in positive effects on the physical-chemical properties of the dough. This could be explained by the fact that the polymerisation degree depends on the number of available reactive glutamine and cysteine residues located on the surface molecule 
(Lorenzen, 2007). At the initial doses of $\mathrm{TG}$, reactions are intensive and exert considerable effects on dough properties, yielding more elastic dough by covalent bonding of protein chains (Yokoyama et al., 2004; Caballero et al., 2005). With square increase of TG doses, significant effects are missing due to the limited number of accessible reactive residues (Jong et al., 2002). In all the three enzymes, with quadratic increase of the initial concentration, there were a positive statistically significant effect to loss modulus (G") of dough made of substandard wheat flour. That contributes to plastic properties of dough and its greater capacity of adaptation to different stresses which are formed during the process.

The initial concentration of lipase caused a more significant decrease of G" values than quadratic concentration, which pointed to the fact that lipase at the initial concentration created more products of hydrolysis (diacylglycerol, monoacylglycerols, glycerol and free fatty acids) capable to form bonds with gluten contributing to strengthening of wheat dough and to the decrease of dough plasticity.

The increase of lipase concentration above its optimal level, a more expressed hydrolytic effect occured which caused the increase of dough viscosity, i.e. G" values. Increased concentrations of xylanase caused a significant increase in G" ( $P$ $\leq 0.1)$. This effect occured due to the hydrolytic activity of xylanase hydrolyzing glycosidic bonds within the xylan, which resulted in a decrease of the degree of polymerisation (Sunna and Antranikian, 1997). The decrease in the degree of polymerisation led to changes in the rheology of dough such as dough development time, consistency, extensibility and resistance to breakage (Sorensen, 2003). Such alteration of consistency in fact represents the increased value of G".

\section{Effect of enzymes on creep and reco- very properties of wheat dough}

The changes in the viscoelastic properties of wheat dough made from wheat flour of substandard quality caused by the addition of transglutaminase, lipase and xylanase were also analyzed by creep-recovery tests. Values of selected parameters maximum creep compliance $\left(\mathrm{J}_{\max }\right)$, elastic part of the maximum creep compliance $\left(\mathrm{J}_{\mathrm{e}} / \mathrm{J}_{\max }\right)$ and zero shear viscosity $\left(\eta_{0}\right)$ are shown in Table 1. The effects of enzymes on the aforementioned parameters are shown through regression coefficients as well (Table 2).

The creep-recovery results are described in terms of creep compliance $\mathrm{J}(\mathrm{t})$ and fitted to a Burgers model for the creep phase (Eq. (2)) and the recovery phase (Eq. (3)) as follows:

$l_{(t)}=J_{00}+J_{\operatorname{me}}\left(1-\exp \left(-t / \lambda_{\text {ret }}\right)\right)+t / \eta_{0}$
$h_{(t)}=J_{\max }-J_{0 r}-J_{\operatorname{mr}}\left(1-\exp \left(-t / \lambda_{\text {rel }}\right)\right)$

where $t$ is the time, $J_{\max }$ is the maximum creep compliance, $J_{0}$ the instantaneous compliance, $\mathrm{J}_{\mathrm{m}}$ the maximum viscoelastic compliance, $\eta_{0}$ is the zero shear viscosity and $\lambda$ is the mean retardation time. In addition, the remaining deformation after creep stress removal represents the viscous component of the maximum compliance $\left(J_{v}\right)$, whereas the recovered deformation $\left(\mathrm{J}_{\mathrm{e}}\right)$ represents the elastic component. Burgers model is applied in linear viscoelastic region, which means that the non-Newtonian viscosity is not dependent on the time of testing (Ferry, 1980). This condition is met when the time of measurement is short as in the presented experiment. The application of lipase significantly decreased maximum creep compliance $\left(J_{\max }\right)$ values $(P \leq 0.1)$, and the effect of $T G$ in the direction of $J_{\max }$ values decrease was even more expressed $(P \leq 0.01)$ (Figure 2). Both enzymes affected the strengthening of dough structure, TG forming inter- and intrapeptide bonds and LP forming bonds of monoglyceride and free fatty acids with gluten.

Generally, LP and especially TG created more elastic properties providing to dough more resistance to maximum deformation due to the action of stress, which can be concluded on the basis of $J_{\max }$ values. The addition of TG resulted in the increase of the elastic part of the $\mathrm{J}_{\max }$ measured under stress of $50 \mathrm{~Pa}$. The increase of zero shear viscosity $\left(\eta_{0}\right)$ values within the in- 
vestigated concentrations was influenced by TG and LP. Lipase had a positive significant linear effect $(P \leq 0.1)$, whereas $T G$ a positive significant square effect to the increase of $\eta_{0}$ values $(P \leq 0.05)$. Even at its initial concentrations, lipase showed a hydrolytic effect to lipids, and the resulting products of hydrolyse (mono- and diacylforms, released fatty acids) influenced the increase of dough viscosity by forming hydrophobic bonds with the gluten proteins (Gerits e al., 2014). With the increase of TG concentration, an increase in dough viscosity was observed, as a consequence of increasing the degree of gluten polymerisation.

Hydrolytic enzyme Xyl in combination with protein cross-linking enzyme TG expressed synergistic effect to the increase of zero shear viscosity values of wheat dough. This effect can be explained by acting of TG on the improved functionality of the flour proteins through the formation of large polypeptides by forming disulphide covalent crosslinks that leads indirectly to a conversion of soluble proteins to insoluble proteins high molecular weight (Larre et al., 2000) resulting in a decreased solubility. On the other hand, endo- $\beta-1.4$-xylanases can alter arabinoxylan (AX) physicochemical properties. They degrade water- extractable AX to lower molecular weight, thereby lowering viscosity inducing properties and partially impairing gelling capacity. They further render water-unextractable AX soluble, resulting in an increase in the viscosity of the medium (e.g. dough) by the solubilised arabino-xylan. The lower viscosity results in better dough machinability (Courtin, 2001).

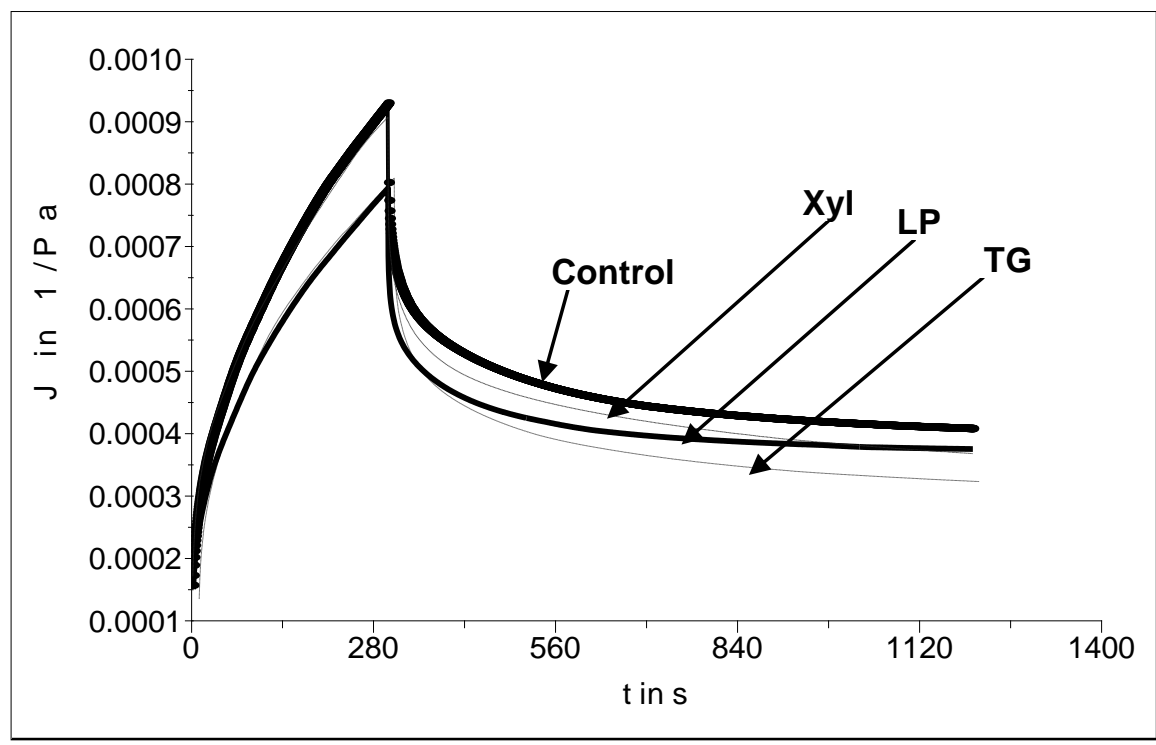

Figure 2. The effect of enzymes on creep-recovery properties of substandard wheat dough

Table 3.

Optimization solutions of TG, LP and Xyl concentration for the set requirements of wheat dough made from substandard quality flour

\begin{tabular}{|c|c|c|c|c|c|c|c|c|}
\hline \multirow[b]{2}{*}{ Parameters } & \multicolumn{3}{|c|}{ Factors } & \multicolumn{5}{|c|}{ Responses } \\
\hline & $\begin{array}{c}\mathrm{TG} \\
\mathrm{mg} / \mathrm{kg}\end{array}$ & $\begin{array}{c}\mathrm{LP} \\
\mathrm{mg} / \mathrm{kg}\end{array}$ & $\begin{array}{c}\text { Xyl } \\
\mathrm{mg} / \mathrm{kg}\end{array}$ & $\begin{array}{c}\mathrm{G}^{\prime} 10^{3} \\
\mathrm{~Pa}\end{array}$ & $\begin{array}{c}\text { G"10 } \\
\mathrm{Pa}\end{array}$ & $\mathrm{J}_{\mathrm{max}^{-1}} 10^{-3}$ & $\begin{array}{c}\mathbf{J}_{\mathrm{e}} / \mathbf{J}_{\max } \\
\%\end{array}$ & $\begin{array}{l}\eta_{0} 10^{4} \\
\text { Pas }\end{array}$ \\
\hline Criteria & $\begin{array}{l}\text { in } \\
\text { range }\end{array}$ & $\begin{array}{l}\text { in } \\
\text { range }\end{array}$ & $\begin{array}{l}\text { in } \\
\text { range }\end{array}$ & $\max$ & $\min$ & $\min$ & $\max$ & $\begin{array}{c}\text { in } \\
\text { range }\end{array}$ \\
\hline Importance & 3 & 3 & 3 & 4 & 4 & 4 & 5 & 3 \\
\hline \multirow{2}{*}{$\begin{array}{l}\text { Optimization } \\
\text { solutions }\end{array}$} & \multicolumn{3}{|c|}{ Desirability: $75.8 \%$} & \multicolumn{5}{|c|}{ Predicted values } \\
\hline & 30.0 & 28.1 & 38.6 & 13.8 & 4.32 & 0.58 & 66.1 & 81.8 \\
\hline \multirow{2}{*}{$\begin{array}{l}\text { Verification } \\
\text { solutions }\end{array}$} & & & & \multicolumn{5}{|c|}{ Actual values } \\
\hline & 30.0 & 28.1 & 38.6 & 13.1 & 4.56 & 0.59 & 66.0 & 80.6 \\
\hline
\end{tabular}




\section{Optimization of concentration of enzy- mes by desirability function approach}

The intensity and direction of individual and interactive effects of the TG, LP and $\mathrm{Xyl}$ in the investigated range depended on the applied dosage, and primarily on the type of enzymes. By determination of optimal doses for all the three enzymes in the optimized mixture it is possible to reach maximal results in the direction of improving characteristics of dough made from wheat flour of substandard quality. Desirability function approach was used to define the optimal doses of selected enzymes resulting the adequate responses regarding the quality of dough made from wheat flour of substandard quality. The proposition of the criteria necessary for the determination of optimal experimental conditions was based upon preliminary experiments and the literature data and is shown in Table 3.

The solution of the proposed criteria in the optimization of the TG, LP and Xyl doses is also shown in Table 3 . Using the set criteria, a solution having $75.8 \%$ desirability was selected. Therefore, this solution was subsequently analysed to compare the predicted responses with measured values in a new experiment with optimal TG (30 mg/kg), LP (28.1 mg/kg) and $\mathrm{Xyl}(28.60 \mathrm{mg} / \mathrm{kg})$ doses. The results of comparison are also given in Table 3. Predicted results: $13.8 \times 10^{3} \mathrm{~Pa}, 4.32 \times 10^{3} \mathrm{~Pa}$, $0.58 \times 10^{-3} \mathrm{~Pa}^{-1}, 66.1 \%$ and $81.8 \times 10^{4} \mathrm{Pas}$ for G', G", J $J_{\max }, J_{\mathrm{e}} / J_{\max }$ and $\eta_{0}$ respectively, obtained under the optimum conditions were close to the experimental results $13.1 \times 10^{3} \mathrm{~Pa}, 4.56 \times 10^{3} \mathrm{~Pa}, 0.59 \times 10^{-3}$ $\mathrm{Pa}^{-1}, 66.0 \%$ and $80.6 \times 10^{4} \mathrm{Pas}$, indicating that the models were adequate to predict these responses.

\section{CONCLUSION}

In this study, the influence of concentration of transglutaminase, lipase and xylanase on the reological properties of substandard quality wheat dough were analyzed by the application of response surface methodology. Transglutaminase expressed a stronger effect on the strength of wheat dough. Increasing TG levels significantly increased storage modulus $\left(G^{\prime}\right)$, elastic part of the maximum creep compliance $\left(\mathrm{J}_{\mathrm{e}} / \mathrm{J}_{\max }\right)$ and zero shear viscosity $\left(\eta_{0}\right)$ of wheat dough from substandard flour, and decreased maximum creep compliance of dough $\left(J_{\max }\right)$. Individual effects of transglutaminase, lipase and xylanase by their intensity and direction was dependent on the applied concentration. The interaction between TG and LP contributed to improved handling properties of dough (increased storage modulus and decreased loss modulus, but not in the domain of statistical significance). When incorporated into the formulation, the optimized levels of $30 \mathrm{mg} / \mathrm{kg} \mathrm{TG}, 28.1 \mathrm{mg} / \mathrm{kg} \mathrm{LP}$ and 38.6 $\mathrm{mg} / \mathrm{kg} \mathrm{Xyl}$ yielded improved quality wheat dough made from substandard quality wheat flour.

\section{ACKNOWLEDGEMENTS}

This study was supported by the Ministry of Education, Science and Technological Development of the Republic of Serbia (Project III No.46005). The authors would like to thank ABF Ingredients Company (Darmstadt, Germany) for donating the sample of enzyme and S. Šolaja from Barentz d.o.o. (Belgrade, Serbia) for his engagement in sample procurement.

\section{REFERENCES}

1. Autio, K., Kruus, K., Knaapila, A., Gerber, N., Flander, L., Buchert, J. (2005). Kinetics of transglutaminase-induced cross-linking of wheat proteins in dough. Journal of Agricultural and Food Chemistry, 53, 1039-1045.

2. Balla, K., Rakszegi, M., Li, Z., Bekes, F., Bencze, S., Veisz, O. (2011). Quality of winter wheat in relation to heat and drought shock after anthesis. Czech Journal of Food Sciences, 29, 117-128.

3. Buchert, J., Selinheimo, E., Kruus, K., Mattinen,M. L., Raija Lantto, R., Autio, K. (2007). Lipase-catalyzed harvesting and/or enrichment of industrially and nutritionally important fatty acids. In: Novel enzyme technology for food applications. Eds. Rastall, R., Woodhead publishing Limited, Cambridge England, pp. 285-309.

4. Butt, M. S., Tahir-Nadeem, M., Ahmad, Z., Tauseef, M.S. (2008). Xylanases in baking industry, Food Technology and Biotechnology, 46, 22-31.

5. Caballero, P.A., Bonet, A., Rosell, C.M., Gómez, M. (2005). Effect of microbial transglutaminase on the rheological and thermal properties of insect damaged wheat flour, Journal of Cereal Science, 42, 93-100. 
6. Colakoglu, A.S. Özkaya H. (2012). Potential use of exogenous lipases for DATEM replacement to modify the rheological and thermal properties of wheat flour dough. Journal of Cereal Science 55, 397-404.

7. Collar, C., Bollain, C. (2004). Impact of microbial transglutaminase on the viscoelastic profile of formulated bread doughs. European Food Research and Technology, 218, 139146.

8. Courtin, C.M., Delcour, J.A. (2001). Relative activity of endoxylanases towards water-extractable and water-unextractable arabinoxylan. Journal of Cereal Science, 33, 301-312.

9. Dupuis, B. (1997). The chemistry and toxicology of potassium bromate. Cereal Foods World, 42, 171-183.

10. Edwards, N. M., Dexter, J. E., Scanlon, M. G., Cenkowski, S. (1999). Relationship of creeprecovery and dynamic oscillatory measurements to durum wheat physical dough properties. Cereal Chemistry, 76, 638-645.

11. Edwards, N. M., Peressini, D., Dexter, J. E., Mulvaney, S. J. (2001). Viscoelastic properties of durum wheat and common wheat dough of different strengths. Rheologica Acta, 40, 142-153.

12. Ferry, J. D. (1980). Viscoelastic properties of polymers. Wiley, New York.

13. Fisher, N., Hutchinson, J.B., Berry, R., Hardy, J., Ginocchio, A.V. Waite, V. (1979). Longterm toxicity and carcinogenicity studies of the bread improver potassium bromate 1. Studies in rats. Food and Cosmetics Toxicology, 17, 33-39.

14. Gallagher, E., O'Brien, C. M., Scannell, A. G. M., and Arendt, E. K. (2003). Use of response surface methodology to produce functional short dough biscuits. Journal of Food Engineering 56, 269-271.

15. Gerits, L. R., Pareyt, B., Decamps, K., Delcour, J., A. (2014). Lipases and Their Functionality in the Production of Wheat-Based Food Systems, Comprehensive Reviews in Food Science and Food Safety, 13, 978-989.

16. Gerrard, J. A., Fayle, S. E., Wilson, A. J., Newberry, M. P., Ross, M., Kavale, S. (1998). Dough properties and crumb strength of white pan bread as affected by microbial transglutaminase. Journal of Food Science 63, 472475.

17. ICC Standard No. 114/1 (1972, revised 1992). Method for Using the Brabender Extensograph.

18. ICC-Standard No 105/2 (1980, revised 1994). Determination of crude protein in cereals and cereals products for food and feed.

19. Jong, G.A.H., Koppelman, S.J. (2002). Transglutaminase catalyzed reactions: impact on food applications. Journal of Food Science, 67, 2798-2806.

20. Joye, I. J., Lagrain, B., Delcour, J. A. (2009). Use of chemical redox agents and exogenous enzymes to modify the protein network during breadmaking - A review. Journal of Cereal Science, 50, 11-21.
21. Larré, C. Denery-Papini, S. Popineau, Y. Deshayes, G. Desserme, C. Lefebvre, J. (2000). Biochemical Analysis and Rheological Properties of Gluten Modified by Transglutaminase. Cereal Chemistry, 77, 32-38.

22. Larre, C., Denery, P.S., Popineau, Y., Deshayes, G., Desserme, C., Lefebvre, J. (2000). Biochemical analysis and rheological properties of gluten modified by transglutaminase. Cereal Chemistry 77, 32-38.

23. Lorenzen, P.C. (2007). Effects of varying time/temperature-conditions of preheating and enzymatic cross-linking on technofunctional properties of reconstituted dairy ingredients. Food Research International, 40, 700-708.

24. Malešević, M., Jaćimović, G., Jevtić, R., Aćin, V. (2011). Exploiting the genetic potential of wheat under conditions of abiotic stress, 45th Conference on agriculture Serbian, Zlatibor, Serbia, Proceedings, pp. 3-14.

25. Mikhaylenko, G. G., Czuchajowska, Z., Baik, B.-K. Kidwell, K.K. (2000). Environmental influences on flour composition, dough rheology, and baking quality of spring wheat. Cereal Chemistry, 77, 507-511.

26. Poulsen C.H., Borch Søe J. (1997). Effect and functionality of lipases in dough and bread, 1st Symposium of Enzymes in Grain Processing. Zeist, Netherlands, Proceedings, pp. 204-14.

27. Primo-Martin, C., Hamer, R.J. and de Jongh, H.H.J. (2006). Surface layer properties of dough liquor components: are they key parameters in gas retention in bread dough? Food Biophysics FOBI 1, 83-93.

28. Rossel, C.M., Wang, J., Aja, S., Bean, S., Lookhart, G. (2003). Wheat flour proteins as affected by transglutaminase and glucose oxidase. Cereal Chemistry, 80, 52-55.

29. Safari-Ardi, M., Phan-Thien, N. (1998). Stress relaxation and oscillatory tests to distinguish between doughs prepared from wheat flours of different varietal origin. Cereal Chemistry, 75, 80-84.

30. Si, J.Q. (1997). Synergistic effect of enzymes for breadmaking. Cereal Foods World, 42, 802807.

31. Si, J.Q., Dost-Lustenberger, C. (2002). Enzymea for bread, pasta and noodle products. In: Enzymes in Food Technology. Eds. Whitehurst, R. J., Law, B., A. Sheffield Academic Press Ltd, pp. 19-54.

32. Šimurina, O., Ikonić, B., Jevtić-Mučibabić, R., Belović, M., Koprivica, G., Mišljenović, N. (2012). Application of response surface methodology in the development of specialty bread with sugar beet molasses, flax seed and vital wheat gluten, Food \& Feed Research, 39, 1122.

33. Sorensen, J.F. (2003). Novel tailor-made xylanases: their characterisation, performance in cereal processing and use as a tool to understand xylanase functionality in baking. in: Recent Advancesin Enzymes in Grain Processing. Eds. Courtin CM, Veraverbeke WS, Delcour J.A. Laboratory of Food Chemistry, 
Katholieke Universiteit Leuven, Leuven, pp. 241-245.

34. Sunna, A., Antranikian, G. (1997). Xylanolytic enzymes from fungi and bacteria. Critical Reviews in Biotechnology, 17, 39-67.

35. Valeri, D., Lopes, A. M., Pessoa-Júnior, A. (2011). Evaluation of xylanases from Aspergillus nigerand Trichoderma sp. on dough rheological properties, African Journal of Biotechnology, 10, 9132-9136.
36. Ylimaki, G., Hawrysh, Z. J., Hardin, R., T., Thomson, A., B., R., (1988). Application of response surface methodology to the development of rice flour yeast breads: Objective measurements. Journal of Food Science, 53, 1800-1805.

37. Yokoyama, K., Nio, N., Kikuchi, Y. (2004). Properties and applications of microbial transglutaminase. Applied Microbiologya and Biotechnology 64, 447-454.

\title{
ПРОМЕНА РЕОЛОШКИХ ОСОБИНА ПШЕНИЧНОГ ТЕСТА НИСКОГ КВАЛИТЕТА У ЗАВИСНОСТИ ОД КОНЦЕНТРАЦИЈЕ ОДАБРАНИХ ЕНЗИМА
}

\author{
Оливера Д. Шимурина* ${ }^{*}$, Бојана В. Филипчев ${ }^{1}$, Тамара Р. Дапчевић Хаднађев ${ }^{1}$, \\ Бојана Б. Иконић ${ }^{2}$, Марија И. Бодрожа Соларов \\ ${ }^{1}$ Универзитет у Новом Саду, Научни институт за прехрамбене технологије у Новом Саду, \\ 21000 Нови Сад, Булевар цара Лазара бр. 1, Србија \\ ${ }^{2}$ Универзитет у Новом Саду, Технолошки фракултет, 21000 Нови Сад, \\ Булевар цара Лазара 1, Србија
}

Сажетак: Циљ рада био је анализа појединачних и синергистичких ефеката три ензимска препарата (трансглутаминазе, липазе и ксиланазе) на вискоеластичне особине теста од пшеничног брашна ниског квалитета. Коришћена алатка у тој анализи је метод одзивне површине (Box-Behnken експериментални дизајн), а резултати су потврдили да је највећи ефекат постигнут појединачним деловањем трансглутаминазе и липазе. Поред тога, сагледана су и синергистичка деловања наведених ензима. Модул еластичности теста је највећи применом трансглутаминасе и липазе у количини од 30 мг/кг и 15 мг/кг, респективно. Са друге стране, синергистичко деловање трангсглутаминазе и ксиланазе повећава вредност вискозитета теста.

Оптималне концентрације тестираних ензима су одређене применом функције пожељности. На вискоеластичне особине теста од испитиваног узорка брашна ниског технолошког квалитета установљен је позитиван интеракцијски ефекат сва три ензима и то у смеши од: 30,0 мг/кг трансглутаминасе, 28,1 мг/кг липазе и 38,6 мг/кг ксиланаза. Допринос рада досадашњим истраживањима је сагледавање пре свега интеракцијских ефеката трансглутаминазе, липазе и ксиланазе на реолошка својства теста од пшеничног брашна ниског квалитета.

Кључне речи: пшенично брашно ниског квалитета, ензими, оптимизација

Received: 21 July 2014

Accepted: 30 September 2014 